\title{
The Dynamic Role of the Bibliothèque wallonne in the History of the Walloon Churches
}

\author{
August den Hollander \\ Vrije Universiteit Amsterdam, Amsterdam, The Netherlands \\ a.a.den.hollander@vu.nl
}

\begin{abstract}
The Bibliothèque wallonne accommodates a church collection that is the result of distinct archival policies. Tracing the archival history of this collection reveals important shifts in its formation, accessibility, and usage. A travelling archive from 1578, it became a fixed church archive in 1777 , and in $185^{2}$ was augmented by a separate Walloon Library, with both archives under the management of a Commission des Archives. In 1877, the Commission de l'histoire des Églises wallonnes was established, whose goal was to write the history of the Walloon churches in the Netherlands, and collecting the necessary sources for doing so. In 1893, after the activities of both commissions were merged, the collections were combined to form what is now the Bibliothèque wallonne. Established primarily as a church archive, the collection is now mostly used for researching the history of the Walloon churches in the Netherlands.
\end{abstract}

\section{Keywords}

Walloon churches - Bibliothèque wallonne - history of archives - Huguenots - church history

\section{Introduction}

The history of archives is still a relatively young discipline. ${ }^{1}$ Historians often turn to the finding aid of an archive to learn about its history. This kind of

1 Erik Ketelaar, "Prolegomena to a Social History of Dutch Archives," in A Usable Collection. Essays in Honour of Jaap Kloosterman on Collecting Social History, ed. Aad Blok, Jan Lucassen 
introduction provides the reader with the necessary background information to make meaningful searches within the archive, but often gives only limited insight in the history of the archive itself. It is clear, however, that archives are not static entities, but have been created in a long and dynamic process, managed by individuals and institutions - such as churches - in constantly changing social and cultural contexts. ${ }^{2}$ The historian of collections and archives studies to what purpose individuals and institutions have shaped, managed, and used historical collections. It is with good reason that the archivist Erik Ketelaar notes that "what is recorded/archived and what is left out, is determined not only by archivalization by powerful actors, but also by seemingly innocent practices of classification, filing, registration, etc." ${ }^{3}$ It is therefore important to stress that archives have "narratives of their own that need to be carefully 'read' before their materials can be fully appreciated and most effectively used." Historians and other users of the archive must therefore "comprehend the conceptual and cultural milieu in which their archival sources are created, structured, processed, appraised, discarded, and preserved." ${ }^{4}$ Historians such as Alexandra Walsham and Jesse Spohnholz stress the importance of exploring the relationship between archival power and narrative structures. ${ }^{5}$ In concrete terms, studying "the ways in which the organization of archives ... influences the formation of knowledge," as well as the (often ideological) narrative framing of these documents. ${ }^{6}$

An interesting example of the relationship between "archival power" and narrative structures (or, if you will, the organisation of the archive and its role in the formation of knowledge) is to be found in the history of the collection of the Bibliothèque wallonne (Walloon library), housed in Leiden's University Library. ${ }^{7}$ The Bibliothèque wallonne can be considered as the official

and Huub Sanders (Amsterdam, 2014), 40-55. See also Elizabeth Yale, "The History of Archives. The State of the Discipline," Book History 18/1 (2015), 332-359.

2 Ketelaar, "Prolegomena" (see above, n. 1), 42.

3 Ibid., 45. See for a good example: Jesse Spohnholz, "Archiving and Narration in PostReformation Germany and The Netherlands," Past \& Present Supplement 11 (2016), 330-348. The notion 'archivalization' was coined by Ketelaar in his "Archivalisation and Archiving," Archives and Manuscripts 27 (1999), 54-61.

4 Ketelaar, "Prolegomena" (see above, n. 1), 55.

5 Alexandra Walsham, "The Social History of the Archive. Record-Keeping in Early Modern Europe," Past \&Present Supplement 11 (2016), 9-48; Spohnholz, “Archiving and Narration" (see above, n. 3), 33०.

6 Spohnholz, "Archiving and Narration" (see above, n. 3), 331.

7 For previous studies on the Bibliothèque wallonne, see: Henk Jan de Jonge, "De terugkeer van de Bibliothèque wallonne naar Leiden," Omslag. Bulletin van de Universiteitsbibliotheek Leiden en het Scaliger Instituut 2004/3 (2004), 2-3; Henk Jan de Jonge, "The Bibliothèque 
archival depository of the Walloon churches in the Netherlands. Although various aspects of its history have already been described, this essay will focus on the three archival shifts that impacted on the record-keeping and collecting practices of the Bibliothèque wallonne, and discuss its early reception. The collection began as a travelling archive managed by an actuary, who took the entire collection with him to each synodal meeting of the Walloon churches. In the seventeenth century, these synodal documents were kept in the Walloon church of Leiden, but it was not until the eighteenth century that this church was made the official depository of the Walloon churches. In the nineteenth century, a working library was set up as a counterpart to the archive. It is in this century that writing the history of the Walloon churches was added to simple record-keeping as one of the goals of collecting and preserving these documents. Gradually archive and library developed into the single repository for the history of the Walloon churches that it is today. As this essay argues, the Bibliothèque wallonne accommodates a church collection that is the result of distinct archival policies that changed over time. Tracing the history of these archival shifts reveals the changing goals in the formation, accessibility, and use of the Walloon collections - changes that will continue as scholars apply new approaches to the history of the Huguenot Refuge.

\section{$2 \quad$ From Travelling to Fixed Church Archive}

Great emphasis was placed on pursuing and maintaining proper administrative records in the first regional meetings of the Walloon churches that took place at the end of the sixteenth century. Local churches were obliged to keep their consistory minutes, diaconal accounts, and baptismal and marriage records up to date. In addition, from 1578 the records and acts of the Walloon

Wallonne," in Special Collections. A Guide to the Collections of Leiden University Library and Neighbouring Institutions (Leiden, 2002), 45-49, 97; Kasper van Ommen, "De Bibliothèque Wallonne," in 'Sicen'est pour nous, alors pour nos successeurs.' Honderdvïftigjaar Bibliothèque Wallonne (exhibition catalogue) (Leiden, 2002), 37-63; Henk Jan de Jonge, "De Waalse Bibliotheek," De Boekenwereld (1985-1986), 2-7; Sijbrandus Johannes Fockema Andreae, "Archives des Églises wallonnes des Pays-Bas," Nederlands archievenblad 57 (1952-1953), 105-121; Émile Bourlier, "La Bibliothèque wallonne. Discours prononcé à l'ouverture de la Réunion des députés des Églises wallonnes assemblés à Maestricht," Bulletin de la Commission de l'histoire des Églises wallonnes 2/3 (1902), 77-107; Willem Nicolaas du Rieu, "De Boekerij van het Walsch Kerkgenootschap te Leiden," De Nederlandsche Spectator 42 (1865), 331-332; Jean Théodore Bergman, "Bibliotheek van het Walsche Kerkgenootschap," Algemeene konst- en letterbode 67 (1855), 310-311. 
synods had been stored in a wooden box, known as the coffre synodal (synodal chest), kept by an actuary and transported throughout the country for each meeting of the synod. This travelling archive consisted of a collection of documents that could be consulted at every meeting, both to ensure that any synodal decision could be supported by the relevant information, and also as it was the most important physical representation of the Walloon churches. ${ }^{8}$

As, over time, the number of documents retained in this travelling archive increased, so, too, did the number of chests required to store them, which brought with it several problems, in particular the inconveniency of transporting the archive to each synod. ${ }^{9}$ Moreover, because of the confidential nature of some of the documents in the archive, only the actuary himself could consult the archive without the explicit permission of the synod. As the position of actuary was not a fixed-term appointment, some ministers kept this position for a long period. The Leiden minister Esaïe du Pré, for example, was actuary from 1619 until $1649 .{ }^{10}$ It was for this reason that in the first half of the seventeenth century, the synodal chests were usually kept in the Walloon church of Leiden. In order that it accord with the rule of equality between the Walloon churches, the synod of 1649 decided that the archive should remain ambulant.1 During the seventeenth century, however, most of the actuaries were Walloon ministers from Leiden, and Leiden would thus remain the de facto home of the archive. In 1689, it was decided to appoint a new actuary every three years, and to give this position in rotation to one of the ministers from the largest Walloon churches in the Netherlands. This regular turnover of actuaries, and the resulting increase in transportation, had a negative impact on the maintenance of the archive. It was perhaps as a result of this that some documents disappeared from the synodal chests, including documents dating from the years immediately following the Revocation of the Edict of Nantes. $^{12}$

For a short introduction to the organisation of the Walloon churches, see G.H.M. Posthumus Meyjes and Hans Bots, eds., Livre des Actes des Églises Wallonnes aux Pays Bas 16011697 (The Hague, 2005), ix-xxviii, esp. xiii-xiv.

$9 \quad$ Fockema Andreae, "Archives" (see above, n. 7), 105-106. In 1733, a second chest was required; by 1776 the actuary looked after such a large archive that two additional chests were needed. See also Émile Bourlier, ed., Livre synodal contenant les articles résolus dans les synodes des Églises wallonnes des Pays-Bas, 2 vols. (The Hague, 1896-1904), 1: 3-15.

Posthumus Meyjes and Bots, eds., Livre des Actes (see above, n. 8), xv. On Du Pré, see Willem Nicolaas du Rieu, "L'Album amicorum' d'Esaie du Pré, pasteur Wallon a Leyde," Bulletin de la Commission de l'histoire des Églises wallonnes 5 (1892), 105-146, esp. 106-109. Posthumus Meyjes and Bots, eds., Livre des Actes (see above, n. 8), xiii-xv. Ibid., xv. 
To remedy these problems, in 1776 the incumbent actuary Louis Appelius, a Walloon minister from Middelburg, suggested that a depository be set up in a centrally located Walloon church. The Walloon synod meeting in Den Bosch in June 1777 agreed, although it also decided to split up the collection: a repository (depôt) in the Walloon church of Leiden was to be established to store those documents that were no longer used on a regular basis, while the active archive, consulted during synodal meetings, remained a travelling collection. A short time later, during the synod of Dordrecht in 1788 , the Walloon church of Haarlem proposed that Leiden be made the general depository of the synodal archive. Thus, it was to be not only a place where the actuary could store the papers that he did not have to consult that often, but where also "the true archives of the Walloon churches", including the "precious relics" that were kept in the synodical chest could be stored. ${ }^{13}$ These documents included, among other things, a copy of the confession of faith of the Walloon churches in the Netherlands from 1580, written by Guido de Brès and signed by all Walloon ministers. ${ }^{14}$

The final decision to set up a Walloon depository was made at the synod of Leeuwarden in September 179o. Jacob-Charles Souchay, the Walloon minister of Leiden, was appointed as administrator. He was already familiar with the documents that were kept in Leiden, because he had drawn up an inventory for the synod. ${ }^{15}$ In addition to the documents already kept in the Leiden repository, it was decided that the archives of those Walloon churches that were either closed or under threat of being suppressed should also be stored here. ${ }^{16}$ In 1803 , Souchay published a detailed inventory of the Leiden archives, published at the end of the acts of the synod of Zierikzee held in June of that year. ${ }^{17}$ From the inventory it becomes clear that the collection kept in Leiden had grown

13 Livre synodal contenant les articles résolus dans les synodes des Églises Wallonnes des Provinces-Unies des Païs-Bas, 5 vols. (1688-1806), 4: June 1788, 23-25 (Mémoire de l'Église de Harlem). As "true archives" the delegates considered a copy of the Walloon confession of faith with the original signatures, as well as the manuscript acts of the oldest synods. The expression "precious relics" was used by Émile Bourlier in his presidential address at the opening of the national meeting (Réunion) of the Walloon churches in Maastricht in 1900: Bourlier, "La Bibliothèque wallonne" (see above, n. 7), 84.

14 University Library (Uв) Leiden, Bibliothèque Wallonne (BW), Archives of the Walloon churches, AW2, 134-136.

15 The inventory by Souchay was published as part of the acts of the synod of Leeuwarden: Livre synodal (see above, n. 13), 4: September 1790, 27-36.

16 Ibid., 10-11 (art. 34).

17 Uв Leiden, BW AW1, 205-206, synodal acts Zierikzee, 1803; ив Leiden, BW AW1, 267, Inventaire des Livres et Papiers appartenans au Synode Wallon de la République Batave qui se trouvent dans le Dépôt confié à la garde de l'Église Wallonne de Leide. 
rapidly. The nature of the collection was also changing: it now also included a large number of printed church books and pedagogical works.

In 190o, about a century after the inventory was published, the Walloon minister Émile Bourlier stated in his inaugural address as president of the annual national convention (réunion) of the Walloon churches that the formation of an archive was not only of historical importance. Rather, it primarily concerned its religious and practical importance: the collection served "to learn from the lessons of the past; to have before our eyes the example of our forebears, and to draw inspiration from their wisdom, prudence, spirit of moderation, and equity, no less than from their faith and their ardent zeal in defending the interests of the churches entrusted to their care."18 For Bourlier, the archive served a key function in Walloon memory culture, as it was intended to aid the formation, consolidation, and development of the Walloon identity and sense of community. Bourlier's address marks a clear shift in the history of the collection of the Bibliothèque wallonne, namely its transition from a first phase of recordkeeping to a second phase of history-writing, a transition that took place in the course of the nineteenth century.

\section{The Initiative for the Establishment of a Working Library}

Four years after the publication of the archive's inventory in 1803, at the synod of Bergen op Zoom in 1807, the Walloon church in The Hague suggested that a Walloon library also be set up..$^{19}$ The idea was to form a counterpart to the archive, a kind of working library for the members of the synod in which they could also deposit their own work. ${ }^{20}$ The church in Leiden would house the library, and Souchay would also become its librarian. The library was to be financed through contributions from all of the churches. The Walloon churches were consulted twice, but still the proposal lacked support, with financial concerns resulting from uncertainties over Napoleon's policies amongst the reasons given. It was, for example, unclear how a Royal decree of 2 August 1808 had to be interpreted. This decree dealt, among other things, with the functioning and finances of churches: ministers' salaries were not paid by the state and the number of ministers was reduced. As a result, plans for the establishment of the Bibliothèque wallonne were shelved.

\footnotetext{
18 Bourlier, "La Bibliothèque wallonne" (see above, n. 7), 81-82.

19 Van Ommen, "De Bibliothèque Wallonne" (see above, n. 7), 37.

20 Bourlier, "La Bibliothèque wallonne" (see above, n. 7), 87-88.
} 
Towards the middle of the nineteenth century, however, the tide changed. Generally, there was a growing awareness of Huguenot heritage in Europe. In France, for example, the 185 os were a crucial decade in that respect: in $185^{2}$ the first Huguenot historical society was founded in Paris (together with a journal, the Bulletin), with the explicit aim to collect manuscripts and books on the history of the Huguenots. ${ }^{21}$ In the Netherlands, the plans for a Bibliothèque wallonne were put forward once again, but this time the initiative did not come from within official church circles but from the Swiss-born Hague bookseller and publisher Jean Louis Charles Jacob, who was a member of the Walloon church in The Hague. ${ }^{22}$ He made the suggestion to Pierre Jean Jaques Mounier, minister of the church in The Hague and at that time also the chair of the Commission wallonne, the governing body of the Walloon churches. Jacob explained his ideas for a Walloon library in a letter to Mounier dated 17 July 1848. He pointed at the libraries of the Anabaptists and Lutherans in Amsterdam, that of the Jansenists in Utrecht, and of the Roman Catholics in Warmond as models for the proposed Walloon library. If the churches wanted such a library, he was willing to part with his own, not inconsiderable, book collection in this field at cost price. ${ }^{23}$ Jacob did have experience in establishing a library such as this. Only a few years earlier, in 1845 , he and his Amsterdam colleague, Frederik Muller, had set up a specialist library for Dutch booksellers who had organised themselves into the Vereeniging ter Bevordering van de Belangen des Boekhandels (Society for the Advancement of Booksellers). Both Muller and Jacob had donated a good part of their own collections and Muller served as its first librarian. This library would grow into the largest European specialist library for the history of the book trade and publishing. ${ }^{24}$

Mounier put the letter on the agenda of the Réunion meeting in Delft in 1848. This time, the delegates were positive about the idea of setting up a library. All that remained was to furnish long-term investments. Since a royal decree

21 Bertrand Van Ruymbeke, "Le Refuge: History and Memory from the 177os to the Present," in A Companion to the Huguenots, ed. Raymond A. Mentzer and Bertrand Van Ruymbeke (Leiden, 2006), 422-441.

22 On Jacob, see Joan van der Wyck, "Het genus bibliomaan J.L.C. Jacob: Een inheemsche variant?," De Boekenwereld 8 (1991-1992), 23-27.

23 Van Ommen, "De Bibliothèque Wallonne" (see above, n. 7), 39-41. See also Otto Stephanus Lankhorst and Paul Gerardus Hoftijzer, Drukkers, boekverkopers en lezers in Nederland tijdens de Republiek. Een historiografische en bibliografische handleiding (Den Haag, 1995), 16, 128. Jacob's letter is included as an appendix to Bourlier, "La Bibliothèque wallonne" (see above, n. 7), 107-109.

24 Lankhorst and Hoftijzer, Drukkers, boekverkopers en lezers in Nederland (see above n. 15), 16. 
issued by King William I in 1816 and the restoration of the Reformed Church as the only state-supported religious body, the Walloon churches had new faith in their future, both spiritually and financially. So the church mills began to turn. Instead of going to Jacob, however, they sought the assistance of JeanThéodore Bergman, a member of the Walloon church in Leiden. Bergman was also an employee of the university library of the city, and therefore had the relevant expertise. ${ }^{25} \mathrm{He}$ sent a plan for a library to the Commission wallonne, and in 1849 a committee of three was set up to provide advice on the plan. ${ }^{26}$ Following the committee's report in 1852, discussed at the Réunion in The Hague, the decision to establish a Walloon library, under the supervision of the Walloon church in Leiden, was finally made.

The goal was to assemble a collection of archival materials, authentic documents, and secondary literature on the history of the Walloon churches in the Netherlands, including those that had closed, and of French Protestantism elsewhere. In 1865, while assistant at Leiden University Library, and long before he became librarian of the Bibliothèque wallonne, Willem Nicolaas du Rieu wrote that the collection "could provide explanations about the doctrine, the history, and the acts of the Walloon churches here in the Netherlands, as well as provide information about the lives of the ministers who served the churches." He also cited "the sources for the history of the French refugiés" and pointed out that these had also been collected outside the Netherlands. ${ }^{27}$ Du Rieu probably meant the Société de l'Histoire du Protestantisme Français (SHPF), whose founders also wished to gather information on refugees and their influence wherever they settled. ${ }^{28}$

The church council of Leiden was now charged with managing both the Walloon archive and the library, and to that end appointed a Commission des Archives. This committee reported annually to the Réunion wallonne and

\footnotetext{
25 A short biography of Bergman, written by himself, was published with a commentary by Willem Nicolaas du Rieu, as "Levensbericht van Jean Theódore Bergman," Jaarboekvan de Maatschappij der Nederlandsche Letterkunde (Leiden, 1879), 35-73.

26 The committee consisted of two ministers (Delprat from Rotterdam and Chantepie de la Saussaye from Leiden) and one elder (Vernède from Utrecht).

27 Du Rieu, "De Boekerij" (see above, n. 7), 331-332.

28 Van Ruymbeke, "Le Refuge: History and Memory from the 1770s to the Present" (see above, n. 21$), 425$.
} 
published a catalogue of new acquisitions every five years. ${ }^{29}$ There were three permanent members on the committee chosen from the members of the Walloon churches, and a representative of the Leiden church council, usually the minister. The three permanent members were all closely connected with the trading and collecting of books: Louis Caspar Luzac (1786-1861), a passionate collector of books and manuscripts, Jean Gérard la Lau (1799-1858), a printer and publisher, and Jean Théodore Bergman (1795-1878), at that time the assistant librarian of the Leiden University Library. ${ }^{30}$ The connections with both the commercial world of books and the university library would remain close in the first decades.

Bergman became the first secretary-librarian. His tasks lay primarily in arranging the collection and the publication of the first catalogue in 1855 and three five-yearly supplements, which together resulted in a large survey catalogue in $1875 .{ }^{31}$ Bergman was assisted in his work on the catalogues by, among others, Willem Nicolaas du Rieu, head librarian of the Leiden University Library and a permanent member of the Commission des Archives since $1862 .{ }^{32}$ After Bergman's death in 1879, Du Rieu succeeded him as librarian of the Bibliothèque wallonne. Du Rieu expanded the library considerably, doubling the collection within a period of ten years. Although the collection also grew through trade and gifts, three quarters of it was the result of purchases, often at auctions. 33

The expansion of the archive was also actively taken up by the Commission des Archives, starting in 1853. After an appeal from the Réunion wallonne, archival documents were received from the Walloon churches of Amsterdam, Leiden, and Haarlem, as well as from the archive of the Commission wallonne. Documents were sometimes also loaned to them for short periods, an arrangement that they often made grateful use of with respect to foreign archives and those of Walloon churches that had closed. The Bibliothèque took this opportunity to make copies or take extracts from documents which, in the case of churches that were under threat or had been closed, remained difficult to obtain. ${ }^{34}$ In his introduction to the Catalogue de la Bibliothèque Wallonne

29 Annual reports in Uв Leiden, BW AW2, 371-372 (period 1853-1878) and 264 (period 18781908).

$30 \quad$ Van Ommen, "De Bibliothèque Wallonne" (see above, n. 7), 41-42, esp. 42, n. 1.

31 Catalogue de la Bibliothèque Wallonne, déposé à Leyde. Publié par ordre de la Réunion des Églises Wallonnes des Pays-Bas, ed. Jean Théodore Bergman (Leiden, 1875).

32 On Du Rieu, see Petrus Johannes Blok, "Levensbericht van Dr. Willem Nicolaas du Rieu," Jaarboek van de Maatschappij der Nederlandsche Letterkunde (Leiden, 1897), 192-218.

33 Bourlier, "La Bibliothèque wallonne" (see above, n. 7), 95-99, esp. 98.

34 In 1852, the Commission des Archives had received the archives of only two Walloon 
déposée à Leide from 1875, Bergman attributed the lack of this material to the fact that much had been destroyed or lost. ${ }^{35}$

If the intent behind the formation of the Bibliothèque wallonne was to collect material for the history of the Walloon churches, the writing of that history was not part of its task. At the Réunion of 1877 , a delegate from the Walloon church in Utrecht, Paul Quirin Brondgeest, suggested that a Commission de l'histoire des Églises wallonnes be set up with the express intent of writing the history of the Walloon churches in the Netherlands. In response, a four-man committee was formed to advise the Réunion on the feasibility of Brondgeest's proposal. The committee presented its first report at the next meeting, in which it stressed the necessity of gathering documents and materials on the formation, development, and interior life of the Walloon churches in the Netherlands. The report pointed to the fact that 60 of the once more than 80 Walloon churches had already disappeared. Following this report, the Réunion set up a broader committee that would be well-placed to write this history. This committee, which had its offices in Leiden, had seven members: the Walloon ministers Ferdinand Henri Gagnebin (Amsterdam) and César Gustave Chavannes (Leiden); Willem Nicolaas du Rieu and Adriaan Justus Enschedé, both of whom were also members of the Commission des Archives; Frederik Daniël Otto Obreen, adjunct archivist and librarian of Rotterdam, and later director of the Rijksmuseum in Amsterdam; and Jan Soutendam, archivist of the city of Delft. ${ }^{36}$

Because the task of this committee largely overlapped with that of the Commission des Archives, it is not surprising that in 1893 the activities of both committees were merged. The management and administration of the library, including the archive, were transferred to what now became the Commission de l'histoire et de la Bibliothèque des Églises wallonnes. This committee submitted a yearly report to the Réunion detailing both its activities and the state

churches that had been closed, Naarden and Franeker. By 1900, it had received material from 33 Walloon churches that had been closed, including the consistory acts of 19 churches.

35 Catalogue de la Bibliothèque Wallonne (see above, n. 31), viii-ix. According to Bergman, some local archives from the southern Walloon churches were also reclaimed in 1824 by the Belgian Ministère du Culte réformé, while other archives were given to local Dutch Reformed churches instead of handing them over to the Bibliothèque wallonne.

$3^{6}$ Willem Nicolaas du Rieu, "Avant-propos," Bulletin de la Commission pour l'histoire des Églises wallonnes 1 (1885), 1-6. 
of affairs regarding the library. No initial progress was made with regard to writing a comprehensive history of the Walloon churches in the Netherlands, partly because, as the committee indicated, the collection was far from complete, but also because of the committee's composition. The majority of its members were not historians but archival professionals, tasked with ordering, managing, and providing access to collections. To remedy the lack of historical research on the Walloon churches, the committee decided to establish a Bulletin. In addition to publishing regular reports on the activities of the committee, including the library's new acquisitions, the Bulletin also had to become a public depository of sources that were necessary for the writing of a future history of the Walloon churches in the Netherlands. As Du Rieu explained in his foreword to the Bulletin's first issue of 1885, it was hoped that readers interested in historical studies "will also provide some documents suitable for inclusion in this journal, and as such will contribute to providing future historians with the necessary data to write the history of these Walloon Churches." ${ }^{37} \mathrm{He}$ also sketched the broad range of subjects that, theoretically, should be raised in the Bulletin. First, it should contribute to the area of church history, with such important topics as the history of the foundation and development of the Walloon churches, the first Refuge in the sixteenth century, the history of the Walloon synods, and the second Refuge in the seventeenth century, as well as doctrine, hymns, the development of the religious canon, and the translation of the Bible. Secondly, it should provide information on topics in the field of political and social history, for example on the fate of the refugees, Walloon foundations and institutions, and statistics about baptism, marriage, and membership rolls. Thirdly, it should provide biographical and genealogical articles on Walloon families or Huguenots whose names the committee had compiled in the so-called Fichier wallon, an index of around two million names of French Reformed individuals in the Netherlands and abroad. Finally, the Bulletin had to offer bibliographical articles and book reviews. All the contributions should be supplemented by various illustrations of family coats of arms, portraits, and buildings.

The Bulletin was published until 1971 and right to the end continued to carry out its role as articulated by Du Rieu in 1885 . To end the series, the Commission de l'histoire et de la Bibliothèque des Églises wallonnes tasked its chair, Henk Jan de Jonge, with compiling an extensive index to the Bulletin, which was published in $1985 .{ }^{38}$ As well as indicating what had been published in the

37 Ibid., 6.

38 HenkJan de Jonge, "Le Bulletin de la Commission de l' histoire des Églises wallonnes (18831971). Table avec index alphabétiques des noms et des matières qui y figurent," Nederlands Archief voor Kerkgeschiedenis 65 (1985), 206-235. 
Bulletin, and the sort of research that had been carried out, it also provides an insight into the genesis of the journal. In its first decades, a good part of the material for the Bulletin was supplied by members of the Commission itself. A certain division of labour becomes apparent, too: Du Rieu took care of the yearly reports of the committee, while Gagnebin focused on the history of local Walloon churches. Enschedé, who was also active in tracking down documents abroad, provided (genealogical) contributions on Walloon inviduals and families; Soutendam saw to the publishing of archive documents or extracts of them; and Bourlier and Eugène Picard (1839-1919) — minister in the Walloon church of Dordrecht - wrote most of the book reviews.

Among the other contributors, the Walloon ministers also occupied an important place. Hendrik de Jager (1834-1903), for example, who served as minister in Den Briel from 1862 until 1892, published a number of articles in the Bulletin on the history of the Walloon church of Den Briel. De Jager had received a small subsidy from the city of Den Briel to work as the city archivist, in addition to his ministerial work. He carried out his obligations as archivist enthusiastically and published in numerous periodicals, including more than 170 minor and major contributions with a strongly archival character in De Navorscher between 1877 and 1903 alone. ${ }^{39}$

With respect to content, most of the articles in the Bulletin were concerned with the history of local Walloon churches, which were usually chronological in structure and referred to a great deal of source material, the contributions of Walloon ministers, genealogies of usually prominent families, and necrologies of Walloon ministers and other prominent individuals. The contributions concerning foreign churches were mainly about or related to Dutch Protestants. Articles on the Huguenot refugees were often editions of local and regional resolutions, or of family documents, such as memoirs or refugee stories, usually written by ministers or prominent families.

The establishment of the Bibliothèque wallonne, the Commission de l'histoire, and the Bulletin strongly exude the spirit of the times and have parallels in other countries. The nineteenth century witnessed a renewed obsession with the past, which led, among other things, to the founding of historical societies across Europe. More particularly, Huguenot societies arose in various places, sometimes with libraries affiliated to them. ${ }^{40}$ In France, as mentioned ear-

39 Jacob Cornelis van Slee, "Levensbericht van Hendrik de Jager, 5 November 1834-7 juni 1903," Jaarboek van de Maatschappij der Nederlandse Letterkunde 1904 (Leiden), 149-181, esp. 178-181 for an overview of his publications in De Navorscher.

40 Van Ruymbeke, "Le Refuge: History and Memory from the 1770s to the Present" (see above, n. 21), 422-441. 
lier, the Société de l'histoire du protestantisme français was founded in 1852, together with a bulletin and a library in Paris. ${ }^{41}$ In 1883 , the Huguenot Society of America was founded in New York, followed in 1885 by the Huguenot Society of London, and a few years by later the Deutsche Hugenotten-Verein. The foundation of Huguenot societies was also fuelled by the approaching bicentenary of the revocation of the Edict of Nantes in $1885 .{ }^{42}$ In addition, Huguenot descendants were stimulated in the quest to discover their past due to the loss of churches (not only in the Netherlands), decreasing membership, and the decline of knowledge of French among the younger generations. ${ }^{43}$

Major similarities can be shown in the nineteenth-century narrative of Huguenots in different parts of Europe, such as the great attention paid to their own church history and family histories, primarily the histories of refugees and the persecutions they had suffered—elements to which Du Rieu had already referred in 1885. In her 2010 study of the Huguenots, Susanne Lachenicht pointed out that this narrative of an international Huguenot diaspora became an important element of a shared supranational memory culture. ${ }^{44}$ In addition, she identifies a strong national narrative, which mainly focused on the important contribution of the Huguenots to the various countries that received them. The Bulletin offered contributions of that nature as well. One example is the speech that the Amsterdam minister Marie Adrien Perk gave on 18 June 1885 as chair of the Réunion wallonne, on the commemoration of the revocation of the Edict of Nantes two centuries before. At the end of his speech, Perk summed up the great advantages of the Huguenots' arrival in the Netherlands, in particular for the Walloon churches: the Refuge had entailed a considerable expansion of the Walloon churches; it had strengthened the bond between the Walloon and French churches; and it had greatly improved the quality of

41 Patrick Harismendy, “'Post tenebras lux' ou cent ans de la Société de l' histoire du protestantisme français," Revue d'histoire de l'Église de France 86 (2000), 717-733. On the bulletin, see André Encrevé, "Les premières années du B.S.H.P.F.," Bulletin de la Société de l'histoire du protestantisme français 148 (2002), 709-733; Anne Reichert, "La Société de l'Histoire du Protestantisme Français et son Bulletin. Un regard protestant sur l'histoire du protestantisme français," Bulletin de la Société de l'histoire du protestantisme français 143 (1997), 64-97.

42 Van Ruymbeke, "Le Refuge: History and Memory from the 1770s to the Present" (see above, n. 21), 430-433.

43 Ferdinand Henri Gagnebin, "Introduction," Bulletin de la Commission pour l'histoire des Églises wallonnes 1 (1885), 6-68, esp. 66-68.

44 Susanne Lachenicht, Hugenotten in Europa und Nordamerika. Migration und Integration in der Frühen Neuzeit (Frankfurt/New York, 2010), 483-486. 
Dutch preaching, which Perk considered long-winded and boring, "monotonous, lifeless, cold, heavy."45

The Bulletin offers few contributions on the development of the Walloon church life in a more general sense or on the development of the religious canon. Subjects like the catechism, canticles, hymns, Walloon liturgy, and biblical versions - which are explicitly stated as part of the programme of the Bulletin - are only presented once. At the same time, one searches in vain for contributions on the relation to other faith communities in the Netherlands or social and economic studies. It would be simple enough to cite a long list of topics that are not present in the Bulletin, but that would, on the one hand, not do justice to the task and purpose of either the Commission de l' histoire or the Bulletin itself-namely, the collection of materials. On the other hand, there is also the danger of unjustly burdening the past with the questions of today.

The sources found in the Bibliothèque wallonne, as well as those in other archives and libraries, offer many opportunities for future research. It is the task of present historiography to rediscover the richness of the source materials present in collections such as the Bibliothèque wallonne in Leiden, as this present volume clearly demonstrates. Both the contributions of Julien Léonard and Chrystel Bernat are great examples of studies on the relation of the Huguenot to other faith communities in the Netherlands.

A possible avenue for future research that relies on these sources is the question of the hybrid identity of refugees, ${ }^{46}$ or the idea that migrants can live for generations in two (or more) cultures in such a way that the existence of a separate migrant culture-including a possible orientation to one's home country-does not necessarily stand in the way of integration into the host country. ${ }^{47}$ The question of the often major social, economic, and cultural challenges of the refugees in their host country also merit further attention, as, for example, the study by Erika Kuijpers on immigration and social rela-

45 Marie Adrien Perk, "La Révocation de l'Édit de Nantes et ses conséquences pour les Églises Wallonnes des Pays-Bas," Bulletin de la Commission pour l'histoire des Églises wallonnes 2 (1887), 1-46, esp. 29-34, citation on 32 .

46 Lachenicht, Hugenotten in Europa (see above, n. 44), 480, 507.

47 Van Ruymbeke, "Le Refuge: History and Memory from the 1770 to the Present" (see above, n. 21), 425, states that orientation to one's home country does not necessarily imply a wish to return to that country. 
tions in seventeenth-century Amsterdam has shown, using baptismal, marriage, and membership registries, archives on care for the poor, and sources on citizenship, work, and housing. ${ }^{48}$ Similar comparative research between migrants of different confessions is also desirable. This was the central aim of the international conference Repenser le Réfuge, of which this volume is one of the results. The content and development of the narrative among Huguenot refugees invites more research that draws a sharper distinction between narratives concerning the refugees' own identity-including the evolution and possible re-experiencing of the remembered identity — on the one hand and the actual integration processes on the other, as discussed in David van der Linden's monograph Experiencing Exile. ${ }^{49}$

The Walloon archive and Bibliothèque wallonne, as well as sources held in other repositories, offer sufficient points of contact to enable a closer analysis of the formation of international networks between Protestants than has yet been undertaken. There are many more strands of history to be teased out of these archives, however, including the relationship with Geneva and the role of the French churches in colonial history. As stated above, the Walloon initiatives fit into the broader picture of Huguenot activity in Europe in the second half of the nineteenth century. In addition to the parallels with Huguenot societies elsewhere in Europe and the shared interest in especially the history of French churches and family histories, the Bibliothèque wallonne is primarily a church collection, oriented in its historical collection to the writing of the history of the Walloon churches in the Netherlands.

\section{7}

\section{Conclusion}

The history of the collection of the Bibliothèque wallonne is a dynamic one. In its first phase the aim of the collection was record-keeping. Since 1578, it was a travelling archive of the Walloon churches, maintained by an actuary. The documents that were kept in the synodal chest clearly reflected the main lines of the church organisation: a church order, a confession of faith, and a growing number of acts, letters, and files. For several reasons, the ideal of an ambulatory archive was hard to sustain, and in 1777 a central repository was established in the Walloon church of Leiden. The archive was subsequently

48 Erika Kuijpers, Migrantenstad. Immigratie en sociale verhoudingen in $17^{e}$-eeuws Amsterdam (Hilversum, 2005).

49 David van der Linden, Experiencing Exile. Hugenot Refugees in the Dutch Republic, 16801700, (Farnham, 2015), esp. 163-176 on refugee memoirs. 
split up in a travelling archive, with documents that were still brought by the actuary to every synod, and a repository where the other documents were kept. In 179o it was decided by the Walloon synod to change this repository into a true archive of the Walloon churches, under the supervision of Souchay, one of the Leiden Walloon ministers. This depot was also where relevant documents, such as those of the closed Walloon churches, could be stored.

The second phase in the history of Bibliothèque wallonne started in the nineteenth century, when the focus in the collection shifted from recordkeeping to history-writing. The nineteenth century was marked with a great obsession with the past, which led, for example, to the founding of historical societies across Europe. As a result, Huguenot societies arose in France and the countries of the Refuge, sometimes with libraries affiliated with them. The foundation of a Walloon library in $185^{2}$ and the installation of a Commission des Archives were both meant to expand the number of sources that were available for writing the history of the Walloon churches, and entirely fit in with this broader development. The actual writing of the history of the Walloon churches was the goal of the Commission de l'histoire des Églises wallonnes, installed in 1877. The Commission de l'histoire focused primarily on collecting relevant sources, and in 1885 launched a Bulletin to publish materials for such a history. The Bulletin was published until 1971 and adhered to its original purpose right to the end.

In 1893, a third phase began, in which all Walloon historical collections were brought together into what is now called the Bibliothèque wallonne. The management and administration of the merged Walloon collections were transferred to what became the Commission de l'histoire et de la Bibliothèque des Églises wallonnes. In the twentieth century, the Bibliothèque wallonne gradually developed into the documentation centre for the history of the Walloon churches. The focus of both the Commission d'histoire and the Bibliothèque wallonne is nowadays on facilitating access to the collections by digitization, and on stimulating research by way of research-fellowships, conferences, and meetings. The international conference Repenser le Réfuge is a good example of this focus. The presentations and accompanying discussions clearly showed the importance of future research into collections such as the Bibliothèque wallonne, as well as the great potential of the materials held in these collections. 